\title{
BMJ Global Health Priorities for global political momentum to end TB: a critical point in time
}

To cite: Kasaeva T, Baddeley A, Floyd K, et al. Priorities for global political momentum to end TB: a critical point in time. BMJ Glob Health 2018;3:e000830. doi:10.1136/ bmjgh-2018-000830

Handling editor Alberto L Garcia-Basteiro

Received 14 March 2018 Accepted 20 March 2018

Check for updates Global Tuberculosis Programme, WHO, Geneva, Switzerland

Correspondence to Dr Ernesto Jaramillo; jaramilloe@who.int
Every year, 24 March is commemorated the world over for the announcement of the discovery of the cause of tuberculosis (TB) by Robert Koch in 1882. Koch's discovery of Mycobacterium tuberculosis paved the way for diagnosing and curing TB, yet, more than 130 years later, this ancient disease still takes a heavy toll on mankind-TB remains the leading cause of death from a single infectious agent and ranks ninth among the top 10 causes of death globally. ${ }^{1}$

WHO's 2017 Global TB Report estimated 10.4 million incident cases of TB (of which 1 million were attributable to HIV), and 600000 cases of multidrug-resistant (MDR) TB and rifampicin-resistant TB. ${ }^{1} \mathrm{~TB}$ also remains the leading killer of people with HIV, with 374000 deaths in 2016. MDR TB represents a growing threat to global health and national security, claiming nearly 240000 lives per year and representing a major component of estimated annual deaths due to antimicrobial resistance. ${ }^{2}$ Although 53 million lives have been saved through global efforts since 2000 , there is no evidence of acceleration in the decline in ТB incidence, mortality and suffering.

Currently, more than $40 \%$ of the estimated global TB burden goes undetected or unreported. Four out of five persons with MDR TB do not receive appropriate treatment. More than half of all people with TB and HIV are not reported to receive care and almost half of reported patients with TB are managed without an HIV test result. ${ }^{1}$ Inadequate patient-centred care and multiple hurdles faced by people with TB, including catastrophic costs, hinder their access to highquality TB care and prevention services.

The Agenda for Sustainable Development and the ongoing health system reforms for universal health coverage (UHC) offer ample opportunity for achieving the milestones and targets of the WHO End TB strategy. Within the UHC framework, dedicated efforts are required to widen access to prevention and care for all forms of TB. These include addressing known risk factors such as HIV, nutrition, smoking, alcohol and other substance use, indoor air pollution, silicosis and non-communicable diseases (notably diabetes and mental health disorders). Tackling the public health crisis caused by MDR TB should be a priority. Closer engagement and inclusion of civil society, and collaboration within and across public and private sectors alike, should be increased.

Funding needs to be substantially increased in order to achieve the goal of ending TB. Financing for TB prevention and care has been increasing for more than 10 years, mostly from domestic sources, reaching an estimated US\$6.9billion in 2017 in low-income and middle-income countries. However, this still fell US $\$ 2.3$ billion short of the estimated US $\$ 9.2$ billion required in 2017 and is much less than the US $\$ 12$ billion estimated to be required in $2020 .{ }^{3}$ Studies consistently show that most of the funding required for TB-specific interventions, and progress towards UHC more broadly, could be mobilised domestically in middle-income countries (84\% of global TB cases in 2017). International donor funding (about US $\$ 2$ billion per year, double the current levels) is required to support low-income countries as well as some middle-income countries that are making the financial transition from mixed sources of funding (domestic and donor) to full domestic funding.

Substantial increases in investment in $\mathrm{TB}$ research and development (R\&D) are also needed, which should more than double from the current levels, to introduce new tools to end the epidemic. About US\$0.7 billion was invested in $2016,{ }^{4}$ compared with an annual estimated requirement of US $\$ 2$ billion. ${ }^{3}$ The Global Ministerial Conference on Ending TB in Moscow in November 2017 saw a new ray of hope for countering several of the major hurdles hampering progress in the response to TB. The Moscow Declaration to End TB 
set out commitments to urgently accelerate action at the global and country level and included calls for specific actions to be taken by WHO and by partners on the global and national stage, including the civil society, in all the areas of concern noted above. ${ }^{5}$

Recognising that speeding up progress towards the goal of ending $\mathrm{TB}$ requires action across the health sector and beyond, the Moscow Declaration called for the development of a multisectoral accountability framework for TB. Such a framework (which defines commitments; actions; monitoring and reporting mechanisms; and review mechanisms) can be used to galvanise and sustain political commitment and action on TB at both the global and national level, based on a regular cycle of monitoring and reporting, and review. The framework, led by WHO, is now being developed in consultation with a wide range of stakeholders. A draft of the framework will be discussed at the World Health Assembly in May 2018, and presented at the UN high-level meeting on TB in September 2018.

The Moscow declaration also called for accelerated TB $\mathrm{R} \& \mathrm{D}$ to develop transformative tools and interventions. At the national level, governments agreed to take steps, together with all stakeholders, to create research-enabling environments for R\&D on TB through the development of country-specific strategic plans. At the international level, governments agreed to work with WHO and global partners to develop a novel Global Strategy for TB research to enhance research for the development of new tools and innovative strategies for patient-centred services. It is expected that this global strategy would create conditions for increased coordination of research worldwide, promote efficient use of available resources and mobilise additional resources through a more diversified funding base.

The Moscow Declaration helped garner strong support in January 2018 from the WHO Executive Board towards preparations for consideration of a World Health Assembly Resolution in May 2018, to further accelerate action on TB. It is also facilitating the UN General Assembly (UNGA) high-level meeting on TB in September 2018. Members of UNGA recently concluded their deliberations on the modalities of the meeting, including a planned hearing in advance for civil society and other stakeholders to help ensure a meaningful outcome and impact. Parliamentarians, civil society and development partners are working towards ensuring highest-level participation in the meeting.
Global TB response is gaining momentum and world leaders are rising to the challenge, as has been seen recently at the End TB Summit organised on 13-14 March by the Government of India, the Stop TB Partnership and the WHO/South East Asia Regional Office, with participation of the Indian Prime Minister and ministers of several highest-burden countries. The global TB response is on the brink of a new era. The UNGA highlevel meeting represents a unique opportunity to raise the profile of $\mathrm{TB}$ and secure political commitment to catalyse change towards reinvigorated and transformative TB efforts. The focus should now be on New York in September and across the globe in the months preceding and following this landmark event, when commitments will need to translate into measurable and rapid progress to help those affected by this age-old scourge.

Contributors $\mathrm{AB}, \mathrm{KF}, \mathrm{TK}, \mathrm{CL}, \mathrm{NN}, \mathrm{DEW}$ and $\mathrm{MZ}$ contributed to the content. EJ and KW edited the contributions received. All authors agree with the final version.

Funding The authors have not declared a specific grant for this research from any funding agency in the public, commercial or not-for-profit sectors.

Competing interests None declared.

Patient consent Not required.

Provenance and peer review Commissioned; internally peer reviewed.

Data sharing statement № additional data are available.

Open Access This is an Open Access article distributed in accordance with the Creative Commons Attribution Non Commercial (CC BY-NC 4.0) license, which permits others to distribute, remix, adapt, build upon this work non-commercially, and license their derivative works on different terms, provided the original work is properly cited and the use is non-commercial. See: http://creativecommons.org/ licenses/by-nc/4.0/

(C) Article author(s) (or their employer(s) unless otherwise stated in the text of the article) 2018. All rights reserved. No commercial use is permitted unless otherwise expressly granted.

\section{REFERENCES}

1. World Health Organization. Global tuberculosis report 2017 (WHO/ HTM/TB/2017.23). Geneva: World Health Organization, 2017.

2. The Review on Antimicrobial Resistance. Tackling drug-resistant infections globally: final report and recommendations. 2016 https:// amr-review.org/Publications.html (accessed 14 Mar 2018).

3. UNOPS. The paradigm shift 2016-2020: The global plan to end TB. Stop TB partnership. Geneva: UNOPS, 2015.

4. World Health Organization. Global investments in Tuberculosis research and development: past, present and future: a policy paper prepared for the first WHO global ministerial conference on ending tuberculosis in the sustainable development era: a multisectoral response. WHO/HTM/TB/2017.26. Geneva, 2017.

5. World Health Organization. Moscow declaration to end TB. Moscow. 2017 http://www.who.int/tb/features archive/Online Consultation MinisterialConferenceDeclaration/en/ 